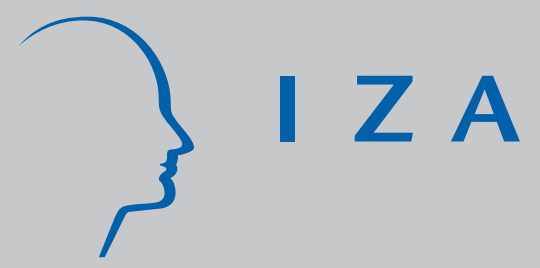

IZA DP No. 962

Norm-Based Trade Union Membership:

Evidence for Germany

Laszlo Goerke

Markus Pannenberg

December 2003 


\title{
Norm-Based Trade Union Membership: Evidence for Germany
}

\author{
Laszlo Goerke \\ Johnannes Gutenberg University of Mainz, \\ CESifo and IZA Bonn \\ Markus Pannenberg \\ DIW Berlin and IZA Bonn
}

\section{Discussion Paper No. 962 \\ December 2003}

\author{
IZA \\ P.O. Box 7240 \\ D-53072 Bonn \\ Germany \\ Tel.: +49-228-3894-0 \\ Fax: +49-228-3894-210 \\ Email: iza@iza.org
}

This Discussion Paper is issued within the framework of IZA's research area Welfare State and Labor Market. Any opinions expressed here are those of the author(s) and not those of the institute. Research disseminated by IZA may include views on policy, but the institute itself takes no institutional policy positions.

The Institute for the Study of Labor (IZA) in Bonn is a local and virtual international research center and a place of communication between science, politics and business. IZA is an independent, nonprofit limited liability company (Gesellschaft mit beschränkter Haftung) supported by Deutsche Post World Net. The center is associated with the University of Bonn and offers a stimulating research environment through its research networks, research support, and visitors and doctoral programs. IZA engages in (i) original and internationally competitive research in all fields of labor economics, (ii) development of policy concepts, and (iii) dissemination of research results and concepts to the interested public. The current research program deals with (1) mobility and flexibility of labor, (2) internationalization of labor markets, (3) welfare state and labor market, (4) labor markets in transition countries, (5) the future of labor, (6) evaluation of labor market policies and projects and (7) general labor economics.

IZA Discussion Papers often represent preliminary work and are circulated to encourage discussion. Citation of such a paper should account for its provisional character. A revised version may be available on the IZA website (www.iza.org) or directly from the author. 
IZA Discussion Paper No. 960

December 2003

\section{ABSTRACT}

\section{Norm-Based Trade Union Membership: Evidence for Germany*}

In the absence of closed-shops and discriminatory wage policies, union membership can be explained by the existence of social norms. We describe a model, incorporating institutional features of the German labour market, which explicitly allows for social custom effects in the determination of union membership. Using panel data for Germany, we find evidence for according effects which restrict freeriding. The impact of social norms tends to increase with net union density. Hence, observed reductions in the demand for union membership can weaken the impact of a norm and accentuate the free-rider problem.

JEL Classification: D71, J51

Keywords: Germany, norms, social custom, trade union membership

Corresponding author:

Laszlo Goerke

Johannes Gutenberg University of Mainz

Department of Economics (FB 03)

55099 Mainz

Germany

Email: Laszlo.Goerke@uni-mainz.de

Tel.: +49 (0) 6131-39-20143

\footnotetext{
* The authors would like to thank Bernd Fitzenberger, Jenny Hunt, Joachim Wagner and Axel Werwatz for comments on a previous version of the paper, where we looked at cross-country differences between West Germany and the UK using cross sections of the GSOEP and the BHPS. All remaining errors are our responsibility.
} 


\section{Introduction}

Why do people become members of a trade union if it is not mandatory but costly to be one? In general, all employees covered by collective bargaining agreements obtain the same wage and face the same working conditions, irrespective of their union status. In 2000 for example, approximately $63 \%$ of the employees in West Germany and roughly $46 \%$ of their East Germany counterparts were covered by industry-wide collective bargaining agreements, while the respective figures for firm-specific agreements amounted to 7\% in West Germany and $10 \%$ in East Germany (Kohaut and Schnabel 2003). In view of this high collective bargaining coverage wages as well as working conditions set by collective agreements are an important benchmark due to a union deterrence effect (Franz and Fitzenberger 1999, Kohaut and Schnabel 2003). Thus, free-riding on union activity seems to be a dominant strategy for employees (Olson 1965). This interpretation would be consistent with the remarkable decline in union density. In Germany, unions have lost more than 4 million members between 1991 and 2000, i.e. about 30\% of their 1991 membership (cf. Ebbinghaus 2003). Figure 1 illustrates the development of union membership in Germany (including the eastern part from 1991 onwards) for different indicators of union density until 1997, the last year for which all according measures were available.

Figure 1: Trade Union Density in Germany 1950-1997

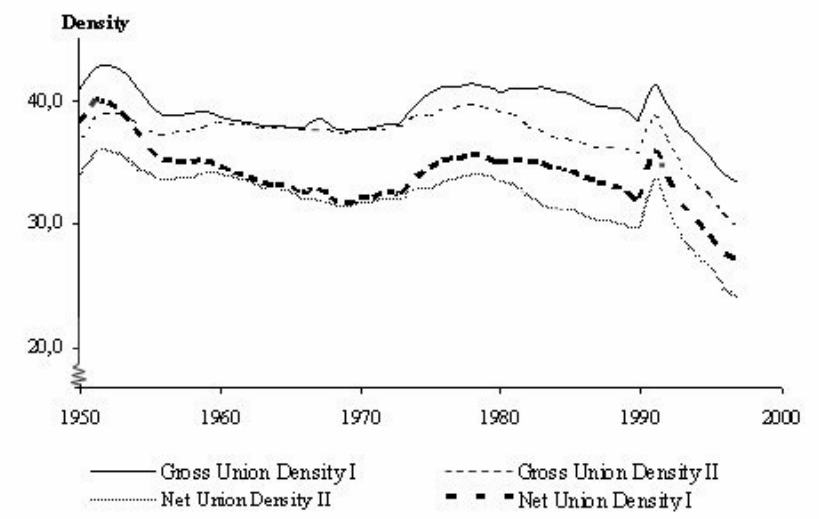

Source: Ebbinghaus and Visser (2000), tables 13 and 14 of CD-ROM for Germany.

Notes: Gross Union Density I: entire union membership as share of gainfully employed wage and salary earners (excluding unemployed) Gross Union Density II: entire union membership as share of dependent labour force (including unemployed). Net Union Density I (II): active membership as share of gainfully employed wage and salary earners (dependent labour force), where active members do not include students, conscripts and pensioners.

After a short upsurge in membership in the 1950s, density, irrespective of whether it in- or excludes unemployed in the denominator or non-working members in the numerator, remained basically stable until the first oil price shock, then rose and fell off in the 1980s. 
Unification sharply increased union density, before the decline mentioned above set in. One successful strategy for unions to counter the decrease in membership might be to stress their role as a movement that provides specific social values (Calmfors et. al. 2001, pp. 132-134). In Germany, unions have actually gone along these lines within the last few years emphasising their particular importance for preserving "social standards in a globalizing world".

In this paper, we try to assess how successful a strategy of promoting "social values" might be. Our central objective is to test whether social custom effects have an impact on individual decisions to join or leave a union and to disentangle the nature of these effects. We proceed as follows: in Section 2, we review the theoretical and empirical literature on norm-based trade union membership. In Section 3, we then sketch a theoretical model based on the institutional features of the German labour market which clarifies how social norms might affect the decision to join a union. The social custom element of this model is subsequently put to an empirical test using data from the German Socio-Economic Panel (GSOEP) for the period 1985-1998. While previous analyses for Germany have focussed on the probability of being a union member, this study represents, to the best of our knowledge, the first empirical investigation of the decision to join or leave a trade union. Moreover, the social custom explanation of union membership has not been explicitly looked at before. Subsequent to a brief description of the data and the variables in Section 4, we outline our empirical specification in Section 5. Section 6 contains the empirical results. Conclusions are found in Section 7.

\section{Determination of Union Membership - a Review of Contributions}

The hypothesis underlying our analysis is that the existence of a norm or social custom can help to solve the apparent free-rider puzzle of trade union membership. This notion goes back to Akerlof (1980) who looks at the impact of a social custom on wage determination, in order to explain persistent unemployment. ${ }^{1}$ The idea was taken up by Booth (1985) to rationalise union membership in a setting with homogeneous agents. Social custom models of trade

\footnotetext{
1 Social custom approaches have, furthermore, been utilised to model labour supply (de Neubourg and Vendrik 1994), strikes (Naylor 1989, 1990), tax evasion (Myles and Naylor 1996), work effort (Chang and Lai 1999), police corruption (Chang et al. 2000), pre-marital sex (Cameron 2001), and adherence to environmental regulations (Lai et al. 2003).
} 
union membership with heterogeneous individuals have been presented by Booth and Chatterji (1993), Corneo (1993, 1995), Naylor and Cripps (1993), Naylor and Raaum (1993), and Goerke (1997). Alternatively, Booth and Chatterji (1995), Moreton (1998, 1999), and Holmlund and Lundborg (1999) have assumed that the heterogeneity of individuals results from differential preferences over private goods. Accordingly, the various approaches can be differentiated with respect to the source of heterogeneity among individuals. Moreover, the scope of bargaining, the treatment of unemployed, and the objective of the analysis differ.

Turning to the source of heterogeneity, it has been assumed that trade union membership yields a reputational gain $r$ which increases utility and which varies across individuals. Reputation $r$ due to membership has been defined as independent of union membership or density $\mathrm{m}$ (Corneo 1993), as the product of the individual-specific reputation effect $\delta$ and union density $\mathrm{m},{ }^{2}$ or as decreasing with density (Corneo 1997). As an alternative, trade unions have been assumed to provide private services solely to members, such as grievance procedures or improved job security (Booth and Chatterji 1995, Moreton 1998, 1999, Holmlund and Lundborg 1999). Since it is our objective to analyse the validity of the social custom model for Germany, we assume that heterogeneity of individuals is due to their differential attitudes towards a norm of union membership. Moreover, because the nature of the social custom effect is theoretically and empirically uncertain, we allow for a flexible relationship between, on the one hand, reputation $r$ and, on the other hand, density $m$ and the individual-specific reputation element $\delta$. Implicitly, the differential modelling approaches also make alternative assumptions with respect to the nature of the social custom effect. If reputation increases with density, the norm may be regarded as outcome-oriented since its impact is influenced by the result in terms of the behaviour of other individuals. All specifications, however, also involve an individual-specific element, which captures the importance of 'internal' norms, affecting individual behaviour for any societal outcome.

Turning to the scope of bargaining, virtually all contributions presume that solely wages are determined collectively and that union preferences are given by those of the median member. Only Corneo (1993, 1995) and Lai et al. (2001) model efficient bargains. In the context of a median voter model, the question arises of how preferences over two items - wages and

2 See Booth (1985), Booth and Chatterji (1993), Corneo (1995), Goerke (1997), and Lai et al. (2001). A slightly more general specification is chosen by Naylor and Raaum (1993) (and Naylor and Cripps 1993) who assume that the marginal gain from membership increases (does not fall) with the strength of the individualspecific reputation effect. Naylor and Cripps (1993) assume, in addition, that also non-membership represents a social custom which yields reputational gains for those who adhere to it. 
employment - are aggregated consistently. Corneo (1993, 1995) circumvents this issue by assuming risk-neutral workers. In an efficient bargaining setting, this assumption entails no unemployment, such that union members effectively only have to vote over the union's wage preferences. Lai et al. (2001) presume that a union executive maximises the sum of the expected utilities of members, without recourse to a mechanism of preference aggregation.

Since workers decide about union membership prior to the determination of employment in all of the above models, some union members will be unemployed if firms determine employment along a labour demand curve. As a consequence, unemployed union members are usually assumed to leave the union and to be refunded their membership fees. ${ }^{3}$ This assumption ensures that equilibrium union membership is determined by the employees' behaviour but is in conflict with the available evidence for Germany. While union membership of unemployed may be a somewhat recent phenomenon, in 1998 12.3\% (30.7\%) of all members of the metal workers' union, the IG Metall, were unemployed in West (East) Germany. Data for other unions also suggest a substantial fraction of unemployed members. ${ }^{4}$ Accordingly, our theoretical model allows for continued membership of unemployed workers. Focussing, lastly, on objectives, earlier contributions explore the functioning of the basic model, for example with respect to exogenous variables such as the alternative income, the membership fee, the social custom variable or demand shocks (Booth and Chatterji 1993, Naylor and Cripps 1993). Later contributions concentrate on an empirical verification of the private good model (Booth and Chatterji 1995), management opposition to union formation (Naylor and Raaum 1993, Corneo 1993, 1995), employment consequences of tax changes (Goerke 1997), the joint determination of union membership and labour productivity (Moreton 1998, 1999), the impact of the Gent system of unemployment insurance (Holmlund and Lundborg 1999), and the consequences of a currency devaluation (Lai et al. 2001).

While the relevant theoretical contributions all assume a social custom of trade union membership, the empirical evidence on the existence and impact of such norms is scarce. To

3 An according assumption is, for example, made by Booth and Chatterji (1993, 1995), Goerke (1997), Moreton (1998, 1999), and Lai et al. (2001). Only Holmlund and Lundborg (1999) presume that unemployed workers remain union members.

4 At the beginning of 2003, 302,000 out of 2,615 million members of the IG Metall (i.e. 11.6\%) were unemployed. About a decade ago, that is in 1993 (1994), 17\% [7.4\%/16\%] of the members of the GTB (Gewerkschaft Textil und Bekleidung) [ÖTV (Öffentliche Dienste, Transport und Verkehr)/ HBV (Gewerkschaft Handel, Banken und Versicherungen)] were unemployed (Ebbinghaus and Visser 2000, country chapter on Germany, Die Zeit, March 20, 2003, p. 23). Note that these unions no longer exist but have merged. According to Ebbinghaus (2003), in 1984/5 the fraction of unemployed members in German unions for which data were available, ranged between $1 \%$ and $7.4 \%$. 
the best of our knowledge, only four studies have explicitly investigated these issues so far: none of them covers Germany or uses a longitudinal panel data design to estimate the parameters of interest. ${ }^{5}$ For Italy, Checchi and Corneo (2000) using macro-data, provide correlations of aggregated social custom effects and aggregated union membership, the norm being proxied by the percentage of leftist votes. However, using macro data they cannot test whether social norms have an impact on the individual decision to join or leave the union. Visser (2002) finds that the probability of joining a union goes along with a pro-union attitude, the perceived pro-union climate and the perceived union density, using two surveys of Dutch employees. For a cross sectional data set of British university employees, Ingham (1993, 1995) estimates that the probability of union membership increases with the partner being a union member and the perceived union density. Neither of these three studies can disentangle the impact of individual unobserved effects and the consequences of social norms on the decision to join or leave the union, since they either do not exploit the panel structure of the data set (Visser 2002) or only utilise a cross sectional data set (Ingham 1993, 1995).

\section{Determination of Union Membership - a Theoretical Framework}

In this section, we provide an outline of the theoretical model which governs our empirical specification. The formal details are relegated to appendix I. The complete theoretical model consists of, on the one hand, a mechanism which determines which employees become union members and, on the other hand, a system of wage determination. Since our study seeks to investigate the social custom theory of trade union membership, potential union members are assumed to trade-off the cost of membership and the increase in reputation $r$ owing to an adherence to the social custom. This trade-off is influenced by the prevailing wage and the level of union density. Wages are the outcome of a Nash-bargain between the trade union and firm. The union's behaviour is governed by the median member. Since the identity of the median member and, hence, the union's preferences depend on union density, wages and membership are determined jointly in equilibrium. The timing of decisions is as follows: first, employees decide about union membership, rationally anticipating the (equilibrium) union density and wage level. Second, wage determination takes place. On the basis of this wage, firms determine employment. Our theoretical framework differs from earlier contributions in two aspects: first, in line with current behaviour of German unemployed, we allow workers

5 While there are other studies focussing on the determinants of being a union member in Germany, such as Beck and Fitzenberger (2003), Fitzenberger et al. (1999), Lorenz and Wagner (1991), Schnabel and Wagner 
without jobs to remain union members. Second, we do not impose a functional form on the reputation function a priori.

Following the earlier discussion, we distinguish three types of social custom effects in our model: (a) The benefits from union membership are an increasing function of union density. We might interpret this as an indication of conformist attitudes by employees. (b) Reputation is independent of the size of the union. This can be labelled unionism founded in sovereignty. (c) Additional reputation might be derived from being a union member while other workers do not belong to it. Such unions are based on elitist behaviour, to employ Corneo's (1997) terminology. The alternative assumptions can formally be captured by a general reputation function $\mathrm{r}^{\mathrm{i}}$, which relates the utility from membership to characteristics of the individual $i$, the size of the union and a shift parameter R (Goerke 2002).

$$
r^{i}=R+\left(\gamma^{i}-\beta\right) m^{\eta}, \text { where } \eta \geq 0
$$

The parameter $\gamma^{\mathrm{i}}$ indicates the individual-specific element of the valuation of unions, where people with a high valuation of unions are characterised by a greater value of $\gamma$. The parameter $\eta$ indicates whether union density $m$ has an impact on the reputation from union membership, that is, whether the norm also involves an outcome-oriented component. A value of $\eta=0$ indicates sovereignty. For $\eta>0$, a value of $\beta \leq 0$ implies that reputation is unambiguously increasing with union density and according empirical evidence can be interpreted as an indication of conformity. The special case of linearity $(\eta=1)$ has usually been investigated. If $\beta=1$ and $\eta>0$ hold, reputation will decline with union density for all but the initial union member, and according empirical results can be viewed as evidence of elitism.

Let the utility of a worker $\mathrm{i}$ be additively separable in the utility $\mathrm{u}$ from income and the utility derived from union membership $\mathrm{r}^{\mathrm{i}}$. Since union members have to pay a wage dependent membership fee $\mathrm{g}$ in Germany, the income of an employed unionist consists of the wage w less the fee $\mathrm{g}$, and amounts to $\mathrm{w}(1-\mathrm{g})$. The resulting utility is given by $\mathrm{u}(\mathrm{w}(1-\mathrm{g})), \mathrm{u}(\cdot)$ being strictly concave, $\mathrm{u}^{\prime}>0, \mathrm{u}^{\prime \prime}<0$. If, as feasible in Germany, an unemployed worker chooses to remain in the union, $\mathrm{s} /$ he will receive reputational utility $\alpha \mathrm{r}^{\mathrm{i}}$, where $0 \leq \alpha<1$, pay a minimal 
fee, which we normalise to zero, ${ }^{6}$ and obtain unemployment benefits $\mathrm{B}, 0<\mathrm{B}<\mathrm{w}$. The probability that a worker is employed (unemployed), assuming a random draw from the population, is $\mathrm{N}<1(1-\mathrm{N})$, where $\mathrm{N}$ describes aggregate employment and labour supply has been normalised to unity. In Germany, it is explicitly forbidden to discriminate workers because of union membership. Accordingly, union members and non-unionists are paid the same wage.

An employee will join the union if the expected gain $Z$ from doing so is positive. For an individual $\mathrm{i}, \mathrm{Z}^{\mathrm{i}}$ is defined by (see appendix I):

$$
Z^{i}=N(w)[u(w(1-g))-u(w)]+\left[R+\gamma^{i} m^{\eta}-\beta m^{\eta}\right][N(w)(1-\alpha)+\alpha]
$$

With the probability N, a worker is employed and obtains the utility from the wage w less the membership fee wg, instead of the utility from the wage. Accordingly, the first term in equation (2) represents the utility loss owing to the monetary cost of union membership. The gain - the second term in (2) - is due to the reputation effect which a member receives either in full with the probability of employment $\mathrm{N}$ or as a fraction $\alpha$ of the maximum impact with the probability of unemployment $1-\mathrm{N}$. A given individual i will be more likely to be a union member, the higher the individual-specific reputation effect $\gamma^{i}$ or the greater the product $\gamma^{i} m^{\eta}$ is. For $\beta \leq 0$, union membership will also be more likely the higher union density is, if $\eta>0$ holds. A rise in wages has ambiguous consequences on the likelihood of membership. In an equilibrium, wages and union density ensure that, first, there are no incentives to join or leave the union from an ex-ante perspective and, second, they are compatible with the outcome of a union-firm bargaining process. To illustrate this equilibrium, note that joining

6 This is a reasonable assumption with respect to German unions, as the information derived from the unions' statutes on membership fees for unemployed workers at the beginning of 2003 indicates.

Monthly Membership Fees for Unemployed in Germany

\begin{tabular}{|l|c|}
\hline \multicolumn{1}{|c|}{ Union } & Membership fee for unemployed \\
\hline IG Metall & $€ 1.50$ \\
\hline Ver.di, IG Bergbau-Chemie-Energie & about $0.5 \%$ of unemployment benefits \\
\hline IG Bauen-Agrar-Umwelt & zero, upon application \\
\hline $\begin{array}{l}\text { Gewerkschaft Erziehung und Wissenschaft, } \\
\text { Transnet, Gewerkschaft Nahrung-Genuss-Gaststätten }\end{array}$ & about $€ 2.50$ \\
\hline
\end{tabular}

Note that there are currently 8 unions in the German trade union federation (Deutscher Gewerkschaftsbund, DGB). Since the union of police officers represents employees which can basically not be dismissed, we have not included this union into our compilation. If the membership fee of unemployed were not normalised to zero, the basic features of the social custom model would not be altered, while the formal apparatus would increase substantially in complexity. 
the union will no longer be advantageous if $Z^{i}=0$. For any given level of the density $m$ it is, therefore, possible to determine that wage $\mathrm{w}$ which makes the marginal member, that is the unionist with the lowest value of $\gamma$, just indifferent between leaving the union and remaining in it. Parametrically varying the level of density $\mathrm{m}$, a membership demand curve MD (Booth and Chatterji 1995) can be derived in the wage-density space. The properties of the MD-curve depend on the assumptions about $\mathrm{r}^{\mathrm{i}}$ and $\mathrm{u}(\cdot)$ (see appendix I). For elitist (sovereign) employees, $\beta=1$ and $\eta>0(\eta=0)$ hold and the MD is upward sloping (cf. figure 2, where linearity has been assumed for simplicity). For conformist workers, $\beta \leq 0$ and $\eta>0$ hold true and the MD is given by a convex parabola (see figure 3). For a given density level, the marginal member will gain utility if the wage rises. Thus, points above (below) the MD imply that employees obtain an increase in utility by joining (leaving) the union, such that density rises (falls). Hence, only the upward sloping section of the MD can be an equilibrium. A higher level of membership $m$ requires workers with lower values of $\gamma$ to join the union. Accordingly, if employees are conformist, there will be a minimum density $s \equiv(1-\beta) \eta /(\eta+$ 1), below which the union will not survive. This cannot be the case for elitist or sovereign workers (see Corneo 1997). The existence of a minimum density level entails potentially disastrous consequences for a trade union which is faced with an exogenous decline in union membership, for example owing to a shift in the sectoral composition of the economy. If employees do not free-ride on the benefits of union activity due to a social custom based on conformity, a reduction in membership can weaken this norm-based behaviour to such an extent that free-riding will become a dominant strategy and the union ceases to exist.

Figure 2: Elitism $(\beta=1, \eta>0)$ or Sovereignty $(\eta=0)$

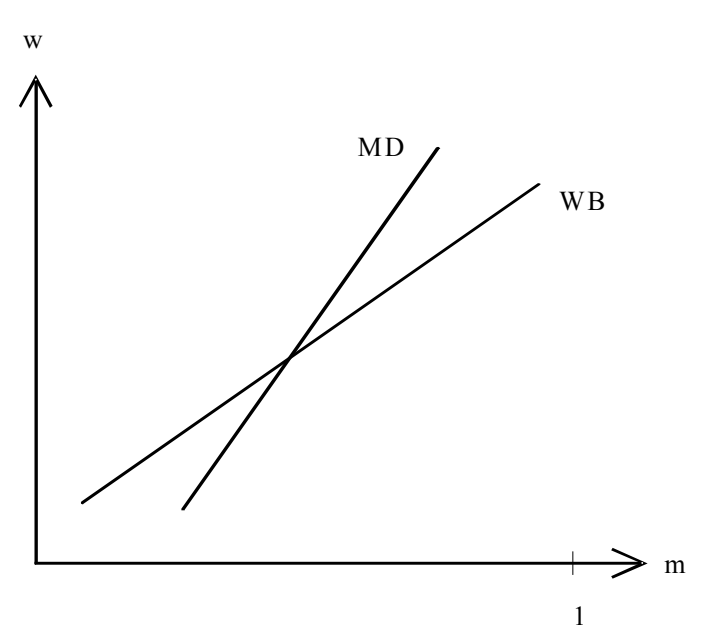

Figure 3: Conformity $(\eta>0, m>2 s, \beta \leq 0)$

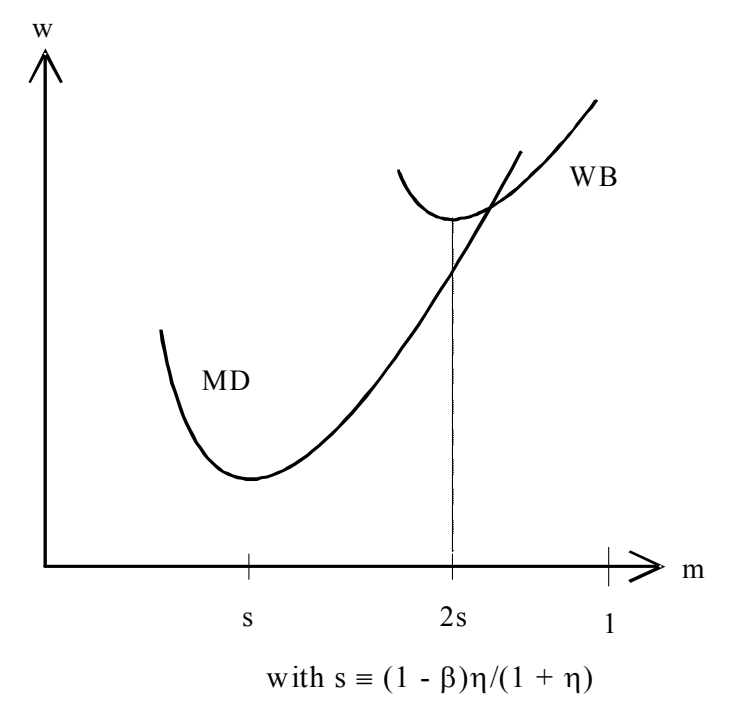


To close the model, a wage determination process is added to the membership demand mechanism. Applying the generalised Nash-solution yields a wage bargaining curve (WB) in the wage-density space (see appendix I for the derivation). The intersection of the WB and the MD determines the equilibrium levels of wages and density. For elitist or sovereign employees $[\beta=1$ and $\eta>0$ or $\eta=0]$, the WB is positively sloped in the wage-density space since a rise in membership decreases the median member's gain from bargaining - $s /$ he is characterised by a lower value of $\gamma$ - such that the negotiated wage has to rise. Assuming stability, the MD increases more strongly than the $\mathrm{WB}$, as depicted in figure $2 .{ }^{7}$ For conformist workers $(\beta \leq 0, \eta>0)$, the WB is downward sloping until union density $\mathrm{m}$ reaches a minimum level given by $\mathrm{m}=2 \mathrm{~s}$. Up to this point, reputation of the median member increases with density because the gain from adhering to the norm outweighs the decrease in the individual reputation effect such that the product of $\gamma$ and $\mathrm{m}$ becomes larger. Since a rise in density increases the union's gain from bargaining for $\mathrm{m}<2 \mathrm{~s}$, the Nash-solution requires a lower wage. For $\mathrm{m}>2 \mathrm{~s}$, the WB is positively sloped since the individual effect dominates the conformity element of reputation and a higher density reduces the median member's gain from bargaining. The wage has to rise. Stability again requires that the MD has a greater positive slope than the WB. Assuming there are no multiple equilibria, figure 3 depicts a potential outcome.

\section{Data and Variables}

The open shop trade union model postulates that social norms have an impact on union membership decisions and that this influence can depend on interactions of individual attitudes and social norms in the reference group. To put our theoretical model to an empirical test, individual data is required with information on union membership and individual commitment to unionism. Our data stem from the German Socio-Economic Panel (GSOEP), a nationally representative longitudinal data set for Germany, first conducted in 1984 and extended to East Germany in 1990 (cf. SOEP Group 2001, Wagner et al. 1993). It provides data on union membership for the years 1985, 1989, 1993 and 1998 for all available subsamples. ${ }^{8}$ The panel structure of the data allows us to analyse individual decisions to join or to leave a union.

7 The requirements for a stable equilibrium are derived by Goerke and Pannenberg (1998), for example.

8 GSOEP first asked East Germans about their union membership status in 1990, just before German unification. Information collected at this stage may, thus, either relate to membership in the former East 
The crucial task of our empirical work is to find appropriate proxies for the individualspecific element of the valuation of unions $\gamma^{\mathrm{i}}$. Ideally, we would measure individual predisposition based on experimental information about attitudes. However, such information is not available in our data. Since actual behaviour is strongly influenced by own political beliefs as well as by actions of family members (see Naylor and Cripps 1993 or Windolf and Haas 1989), we hypothesise that such information can adequately approximate the individualspecific element of union valuation $\gamma^{\mathrm{i}}$. In particular, we employ two types of social custom proxies: the first one relies on information about the occupational status of the respondent's father, when the respondent was young. The reason being that the early socialisation process within the family is an important determinant of union membership. In particular, we exploit information on whether the respondent's father was self-employed, when the respondent was aged 15, since self-employed people tend to disprove of union activities. The second social custom proxy is based on information about the political beliefs and preferences of the respondent. Our hypothesis is that if the respondent prefers a political party which sympathises with or opposes trade unions, this will be a good indicator for $\gamma^{\mathrm{i}}$. Facing the German political system, we conjecture that supporters of the Social Democrats (SPD) go along with the collective principles of unionism whereas partisans of the more conservative parties, that is the Christian Democrats (CDU) and Christian Social Union (CSU), tend to oppose political activities of unions. ${ }^{9}$

In our theoretical model, the gains or losses from conforming with the social custom of union membership are modified by the individual valuation of the reputation from unionism $\gamma^{i} \mathrm{~m}^{\eta}$ (equation (2)). Hence, we have to interact our social custom proxies with the respondent's relevant industry-specific net union density. Of course we also include the social custom proxies themselves in the regressions. Industry-specific net union densities, i.e. the ratio of employed union members to all employees in that industry, are calculated from the GSOEP

German socialist Freier Deutscher Gewerkschaftsbund (FDGB) or to branches of the then only West German Deutscher Gewerkschaftsbund (DGB). Schnabel and Wagner (2003a) argue that most of the changes in union membership in East Germany for the period 1990 up to 1993 are due to the specific transition process. Moreover, we do not have data for the West German sample for 1990. Therefore, we decided to use the information for East German respondents only for 1993 and 1998.

9 In preliminary random-effects probit regression models of being a union member at a certain point of time we observed significant positive (SPD), respectively negative (CDU/CSU), correlations between union membership status and political preferences in our data; as do other studies (Fitzenberger et al. 1999). 
data, since annual membership statistics provided by the unions do not differentiate by employment status. ${ }^{10}$

Our empirical analysis covers all workers who work part or full time in the relevant year, are not self-employed and aged between 18 and 65. Moreover due to identification issues explained below, we restrict ourselves to workers who switch industries between two subsequent waves with information on union membership. Besides social custom variables we exploit information on gross monthly income, firm size, tenure, experience and regions in our regression exercises. More details on the data can be found in appendix II.

\section{Empirical Specification}

In our model, an employee will join the union if the expected gain from doing so is positive. Equation (2) is, therefore, the core of our empirical specification. Since equilibrium union density and wages are determined jointly in the theoretical model, we investigated in preliminary regressions, whether individual real wages are endogenous within our microeconometric framework. This was done by means of a simultaneous equation model with a union membership equation and a Mincerian wage equation for the available waves of our data separately. It turned out that none of the estimated parameters for real wages was significantly different from zero. ${ }^{11}$ Additionally, we tested for a non-linear effect of lagged net union density on reputation (cf. equation (1)), using our sample of workers who switch industries. Standard tests did not reject the hypothesis of linearity, implying $\eta=0$ or $\eta=1$. Given these findings, we employ a single equation model of union membership including linear effects of union density on reputation and exploit the longitudinal structure of our panel data to identify the effects of social norms on decisions to join or leave a union.

The starting point of our empirical work is the following fixed effects logit specification of the union membership equation (2):

$$
P\left(U_{i j t}=1 \mid X_{i j t}, S_{i j t}, M_{j t}, \alpha_{i}\right)=\frac{e^{\alpha_{i}+\kappa_{1}^{\prime} S_{j i t}+\kappa_{2} M_{j t}+\beta^{\prime} X_{i j t}}}{1+e^{\alpha_{i}+\kappa_{1}^{\prime} S_{j i t}+\kappa_{2} M_{j t}+\beta^{\prime} X_{i j t}}}
$$

\footnotetext{
10 See also Fitzenberger et. al. (1999) for a discussion of this point.

11 Our result is in line with most evidence provided by Fitzenberger et al. (1999) and Wagner $(1990,1991)$ but not with the findings by Lorenz and Wagner (1991) for the year 1985. All these studies also rely on the GSOEP. Note that Lorenz and Wagner (1991) use a yearly income measure that does not allow to disentangle the effects of hourly wages and hours of work.
} 
where $\mathrm{U}_{\mathrm{ijt}}=1$ (i:individual, $j:$ industry, $t:$ year) if the expected utility from joining the union $\mathrm{Z}^{\mathrm{i}}$ is positive and $U_{i j t}=0$ otherwise, $S_{i j t}\left(S_{i j t} \sim \gamma^{i} m^{\eta}\right)$ and $M_{j t},\left(M_{j t} \sim\left[m^{\eta}\right]\right)$ are the social custom variables, $\mathrm{X}_{\mathrm{ijt}}$ is a vector of observable individual characteristics (including the social custom proxies themselves), $\alpha_{i}$ is an individual fixed effect, which captures unobserved time invariant individual characteristics, and $\kappa_{1}, \kappa_{2}$ and $\beta$ are (vectors of) unknown parameters.

To yield consistent estimates of equation (3), we follow Chamberlain (1980) ${ }^{12}$ in maximising the conditional likelihood function $\mathrm{L}^{\mathrm{c}}$ :

$$
L^{c}=\prod_{i=1}^{N} P\left(U_{i j 1}=u_{i j 1}, U_{i j 2}=u_{i j 2}, \ldots, U_{i j T}=u_{i j T} \mid \sum_{t=1}^{T} u_{i j t}\right)
$$

In equation (4) the likelihood for each set of observations is conditioned on its specific $\sum_{t=1}^{T} u_{i j t}$. Intuitively, the conditional distribution of $U_{i j 1}, \ldots, U_{i j T}$, given $\sum_{i=1}^{T} u_{i j t}$, is not informative for $\sum_{t=1}^{T} u_{i j t}=0$ or $\sum_{t=1}^{T} u_{i j t}=\mathrm{T}$ since in these cases the outcome is completely determined and the corresponding probability equals 1 . Therefore, only observations with at least one change in union membership status contribute to the conditional likelihood function (4). In our empirical application we additionally require that respondents switch industries $(j, k)$ between subsequent waves. Empirically, this leads to the case of $t=2$ in our subsample of the GSOEP. Hence, we have to consider the following two probabilities:

$$
\begin{aligned}
& P\left(0,1 \mid \sum_{t=1}^{2} u_{i . t}=1\right)=\frac{e^{\kappa_{1}^{\prime}\left(S_{i k 2}-S_{i j 1}\right)+\kappa_{2}\left(M_{k 2}-M_{j 1}\right)+\beta^{\prime}\left(X_{i k 2}-X_{i j 1}\right)}}{1+e^{\kappa_{1}^{\prime}\left(S_{i k 2}-S_{i j 1}\right)+\kappa_{2}\left(M_{k 2}-M_{j 1}\right)+\beta^{\prime}\left(X_{i k 2}-X_{i j 1}\right)}} \\
& P\left(1,0 \mid \sum_{t=1}^{2} u_{i . t}=1\right)=\frac{1}{1+e^{\kappa_{1}^{\prime}\left(S_{i k 2}-S_{i j 1}\right)+\kappa_{2}\left(M_{k 2}-M_{j 1}\right)+\beta^{\prime}\left(X_{i k 2}-X_{i j 1}\right)}}
\end{aligned}
$$

The corresponding conditional likelihood function is:

$$
L^{c}=\prod_{i=1}^{N}\left(\frac{e^{\kappa_{1}^{\prime}\left(S_{i k 2}-S_{i j 1}\right)+\kappa_{2}\left(M_{k 2}-M_{j 1}\right)+\beta^{\prime}\left(X_{i k 2}-X_{i j 1}\right)}}{1+e^{\kappa_{1}^{\prime}\left(S_{i k 2}-S_{i j 1}\right)+\kappa_{2}\left(M_{k 2}-M_{j 1}\right)+\beta^{\prime}\left(X_{i k 2}-X_{i j 1}\right)}}\right)^{d_{i}}\left(\frac{1}{1+e^{\kappa_{1}^{\prime}\left(S_{i k 2}-S_{i j 1}\right)+\kappa_{2}\left(M_{k 2}-M_{j 1}\right)+\beta^{\prime}\left(X_{i k 2}-X_{i j 1}\right)}}\right)^{1-d_{i}}
$$

where $d_{i}=1$ for the observed sequence $(0,1)$ and $d_{i}=0$ for the sequence $(1,0)$.

\footnotetext{
12 See also Baltagi (2001, pp. 206-208).
} 
Equation (7) reveals that our empirical specification, which relies on industry movers who also switch union membership status, enables us to tackle the "reflection problem" described by Manski $(1993,2000) .{ }^{13}$ Manski points out that it is often difficult to disentangle empirically whether individual decisions depend on the behaviour, attitudes or exogenous characteristics of the reference group (social effects ${ }^{14}$ ) or whether individuals act in the same way because they face similar institutional environments (correlated effects). We deal with this problem in the following way: first, we identify the parameters of interest not only because the social custom variables change over time but also because we observe them for each individual for two different industries in the two periods, since we only analyse workers who switch industries. Nevertheless, one might argue that the observed change in individual union status (either join or leave the union) might be correlated with the industry-specific net union density in $t=2$, i.e. with the union density in the new industry 4 or 5 years afterwards. Therefore, we replace the industry-specific union density in $t=2$ with the lagged union density. In terms of the empirical work, this implies that we explain changes in union membership status for industry movers by observed differences in industry-specific net union densities and their interaction with our social custom proxy in $t=1$. Hence, we argue that the decision to join or leave the union depends on the individual evaluation of the observed difference in the relevant industry-specific net union densities before the respondent actually moves to the new industry. Second, including individual fixed effects in our empirical specification allows us to control for unobserved time invariant individual characteristics, such as internal norms or work motivation, which might lead to sorting into specific industries.

\section{Results}

Table 1 reports the estimated parameters of the conditional fixed effects logit model (equation 7) for three specifications employing different sets of social custom variables. Specification 1 $(C F E-I)$ uses both social custom variables, while the other two specifications (CFE II, CFE III) employ only one of them.

13 For similar strategies see Ichino and Maggi (2000) and Bertrand et al. (2000).

14 Note that Manski (1993, 2000) furthermore distinguishes two types of social effects, i.e. endogenous and contextual (exogenous) ones. The former effect occurs because individual behaviour varies systematically with the behaviour of the reference group, while the latter arises since individual behaviour depends on exogenous characteristics of the group like, for example, attitudes towards work. In our empirical work we cannot disentangle these two types of social effects. 
Considering the general specification with both social custom variables (column 1), the estimated parameter for net union density is significantly positive. Hence, a positive difference in net union densities between the industry of destination and the industry of origin before the respondent actually moves, increases the probability of joining the union in the new industry. Conversely, a negative difference in net union densities raises the probability of leaving the union. This indicates that reputation is increasing with union density. In terms of our theoretical model, the result implies $\eta=1$ and $\beta<0$ and, therefore, points to conformity based unionism. With respect to the social custom proxy "father self-employed when the respondent was 15 years old", the estimated parameter for our proxy of $\gamma^{i} \mathrm{~m}^{\eta}$ is significantly negative, i.e. for the subgroup of workers whose family background was influenced by the self-employment of the father, the reputation effect of union density is significantly lower. Note that we observe this effect controlling for the time invariant main effect "father was selfemployed" itself, which is captured by our individual fixed effect. ${ }^{15}$ Hence, our result demonstrates that it is important to allow for a flexible specification of the relationship between reputation and union density in theoretical models. Finally, given the existence of reputation effects, our findings are not consistent with an interpretation that solely economies of scale in the provision of private services by unions are at work (cf. Booth and Chatterji 1995). Since neither the interaction of the political party preference indicator with union density nor the main effects "prefers Social Democrats", respectively "prefers Christian Democrats/Christian Social Union", are significantly different from zero, we do not find evidence that the reputation effect significantly varies between individuals with different political preferences, once we control for individual fixed effects.

The probability of joining (leaving) a union increases (decreases) with firm size, i.e. nonunion workers who accept a job at a new firm with more employees are more likely to join the union. This is in line with other studies on the probability of being a union member for Germany (Fitzenberger et al. 1999, Schnabel and Wagner 2003b, Lorenz and Wagner 1991). Moreover, we find a positive effect of tenure on the likelihood of joining a union. This suggests for our subsample of industry movers that work experience at the new job, for

15 Schnabel and Wagner (2003b) find in their cross-sectional analysis a positive correlation of a dummy "father was blue-collar worker" and the probability of being a union member for the years 1980 and 1992. 
example in terms of peer pressure (cf. Naylor and Cripps 1993), also matters for decisions to join or leave the union.

The LR-test-statistic indicates that the set of estimated parameters is jointly significantly different from zero (Test_X). Moreover, we perform a Hausman-type test based on the difference between the conditional fixed effects logit model and a standard logit model ignoring the fixed effects to check for time invariant unobserved individual heterogeneity (Test_ $\alpha_{i}$; see Baltagi 2001). We can reject the null hypothesis of no individual fixed effects $\left(\chi^{2}(21)=37.4\right)$. Hence, we observe individual heterogeneity with respect to the union membership decision in our data, as assumed in the theoretical model.

One might argue that family background and political preferences of the respondents are correlated, e.g. respondents tend to prefer the conservatives when their father was selfemployed, and that, therefore, the estimates of column 1 are plagued by multicollinearity. To verify this argument, we use two specifications of the conditional fixed effects logit model where we employ only one social custom proxy at a time. The parameter estimates displayed in column 2 and 3 (CFE II, CFE III) show that our results are robust.

As an additional check of robustness we employ a linear probability model with individual fixed effect ( $\left.L P M_{-} F E\right)$ and estimate a linear version of equation (2) using the sample of industry movers. This enables us to assess whether our results are sensitive to the fact that the conditional fixed effects logit specification is restricted to industry movers who also change their union status while still controlling for time invariant individual heterogeneity. Again, we replace the industry-specific net union density in $\mathrm{t}=2$ with their lagged union density. Since $\mathrm{t}$ $=2$ for every person, the within transformation of the linear fixed effects model is equivalent to estimating the model in first differences. Hence, we identify our parameters by regressing first differences in union status on differences in net union densities and their individual evaluation at the point of origin for industry movers.

- Table 2 -

Columns 1 to 3 of Table 2 reveal that the estimated parameters neither for the net union density nor the individual evaluation of the reputation effect from union density change. ${ }^{16}$

\footnotetext{
16 Since the linear probability model is heteroscedastic, we also calculate heteroscedasticity-consistent standard errors (HCSE) along the lines suggested by Greene (2000, pp. 579). These HCSE's are smaller than the ones presented in Table 1.
} 
Hence, we again find evidence for conformity based unionism that differs with respect to individual family background. ${ }^{17}$

\section{Conclusions}

The central objective of this paper is to investigate the importance of social custom effects for individual union membership. Initially, we develop a model of endogenous union membership based on the institutional features of the German labour market. Our subsequent empirical analysis reveals that social custom effects play a crucial role for the individual decision to join or leave a union in Germany. In particular, we find for people who switch industries (from a to b) that an increase in the lagged difference in net union densities between the new sector (b) and the old sector (a) goes along with an increase in the probability of joining the union. This effect varies across respondents with different social background and points to conformity based unionism, i.e. the individual willingness to join (or leave) a union increases (declines) with industry-specific net union densities.

Although trade unions in Germany obviously face the problem of workers taking a free-ride on union services, our results provide evidence in support of the hypothesis that social custom effects restrict such opportunistic behaviour. This lends support to the observed strategies of unions in Germany of stressing their role as a social movement promoting specific social values. However, the theoretical analysis shows that such a strategy can be riddled with difficulties. If sector-specific net union densities decline due to, for example, shifts in product demand, changes in the composition of the labour force, or the emergence of new, nonunionised firms, the conformity-based social custom effect may be weakened substantially and union density fall below its minimum level. A union strategy focussing on social values may in such a case not overcome but accentuate the free-rider problem. Whether recent union mergers in Germany are a rational response to the problem of minimum union densities is an open issue. On the hand, one might argue that union mergers like Ver.di stabilise union density above a critical value and, therefore, preserve or re-enforce an existing social custom. On the other hand, union mergers have to unite different cultures and this might erode the social custom. Since large-scale union mergers in Germany are a recent phenomenon, the evaluation of these competing effects remains a challenge for future research.

17 The same result holds when we estimate the parameters of the LPM_FE based on the subsample N $=716$ employed for the CFE estimates. 
A further challenge is the determination of additional measures of social customs or norms. As Naylor and Cripps (1993) stress, peer pressure within the firm is a major reason for joining a union. Hence, there is additional demand for social custom proxies of the workplace environment. Moreover, it would be desirable to explicitly compare the impact of pure private good incentives (cf. Booth and Chatterji 1995, Holmlund and Lundborg 1999, Moreton 1998, 1999) with those of social custom effects. Our estimates show that social custom effects exist but - due to the lack of adequate data - we cannot contrast the two hypotheses of how the incentives to free-ride can be overcome. 


\section{References}

Akerlof, G.A. (1980), A Theory of Social Custom, of Which Unemployment May be One Consequence, The Quarterly Journal of Economics 94, 749-775.

Baltagi, B. (2001), Econometric Analysis of Panel Data, $2^{\text {nd }}$ Edition, Wiley \& Sons.

Beck, M. and B. Fitzenberger (2003), Changes in Union Membership over Time: A Panel Analysis for West Germany, ZEW Discussion Paper No. 03-42.

Bertrand, M., E.F.P. Luttmer and S. Mullainathan (2000), Network Effects and Welfare Cultures, The Quarterly Journal of Economics 115, 1019-1055.

Booth, A. L. (1985), The Free Rider Problem and a Social Custom Model of Trade Union Membership, The Quarterly Journal of Economics 100, 253-261.

Booth, A. L. and M. Chatterji (1993), Reputation, Membership and Wages in an Open Shop Trade Union, Oxford Economic Papers 45, 23-41.

Booth, A. L. and M. Chatterji (1995), Union Membership and Wage Bargaining when Membership is not Compulsory, The Economic Journal 105, 345-360.

Calmfors, L., Booth, A.L., Burda, M., Checchi, D., Naylor, R. and J. Visser (2001), The Future of Collective Bargaining Europe, 1-134, in: Boeri, T., Brugiavini, A. and L. Calmfors (eds), The Role of Unions in the Twenty-First Century - A Study for the Fondazione Rodolfo Debenedetti, Oxford University Press.

Cameron, S. (2001), The Economic Analysis of Social Customs: the Case of Pre-marital Sex, Journal of Evolutionary Economics 11, 457-473.

Chamberlain, G. (1980), Analysis of Covariance with Qualitative Data, Review of Economic Studies 47, 225-238.

Chang, J. and C. Lai (1999), Carrots or Sticks? A Social Custom Viewpoint on Worker Effort, European Journal of Political Economy 15, 297-310.

Chang, J., Lai, C. and C. C. Yang (2000), Casual Police Corruption and the Economics of Crime: Further Results, International Review of Law and Economics 20, 35-51.

Checchi, D. and G. Corneo (2000), Trade Union Membership: Theories and Evidence for Italy, Lavore e Relazioni Industriali 2, 151-186.

Corneo, G. (1993), Semi-unionized Bargaining with Endogenous Membership and Management Opposition, Journal of Economics 57, 169-188.

Corneo, G. (1995), Social Custom, Management Opposition, and Trade Union Membership, European Economic Review 39, 275-292.

Corneo, G. (1997), The Theory of the Open-Shop Trade Union Reconsidered, Labour Economics $4,71-84$.

de Neubourg, C. und M. Vendrik (1994), An Extended Rationality Model of Social Norms in Labour Supply, Journal of Economic Psychology 15, 93-126.

Ebbinghaus, B. (2003), Dinosaurier der Dienstleistungsgesellschaft? Der Mitgliederschwund deutscher Gewerkschaften im historischen und internationalen Vergleich, in: Schroeder, W. B. Wessels (eds.), Gewerkschaften in Politik und Gesellschaft in der Bundesrepublik. Westdeutscher Verlag.

Ebbinghaus, B. and J. Visser (2000), Trade Unions in Western Europe since 1945, Macmillan.

Fitzenberger, B., Ernst, M. and I. Haggeney (1999), Wer ist noch Mitglied in Gewerkschaften?, Zeitschrift für Wirtschafts- und Sozialwissenschaften 119, 223-263. 
Franz, W. and B. Fitzenberger (1999), Industry-level Wage Bargaining: a Partial Rehabilitation. The German Experience, Scottish Journal of Political Economy 46, 437-457.

Goerke, L. (1997), An Open Shop, Wage Bargaining, and Taxation - A Note, Oxford Economic Papers 49, 651-657.

Goerke, L. (2002), Taxes and Unemployment, Kluwer Academic Publishers.

Goerke, L. and M. Pannenberg (1998), Social Custom, Free Riders, and Trade Union Membership in Germany and Great Britain, DIW Discussion Paper No. 177.

Greene, W. (2000), Econometric Analysis, $4^{\text {th }}$ Edition, Prentice Hall.

Holmlund, B. and P. Lundborg (1999), Wage Bargaining, Union Membership, and the Organization of Unemployment Insurance, Labour Economics 6, 397-415.

Ichino, A. and G. Maggi (2000), Work Environment and Individual Background: Explaining Regional Shirking Differentials in a Large Italian Firm, The Quarterly Journal of Economics 115, 1057-1090.

Ingham, M. (1993), Characteristics and Customs: Empirical Evidence on the Union-joining Decision, Employee Relations 15, 27-41.

Ingham, M. (1995), Union Joining: an Empirical Test of the Social Custom Model, Applied Economics Letters 2, 245-247.

Kohaut, S. and C. Schnabel (2003), Tarifverträge - nein danke! Einflussfaktoren der Tarifbindung west- und ostdeutscher Betriebe, Jahrbücher für Nationalökonomie und Statistik 223, 312-331.

Lai, C., Chang, J. and W. Chang (2001), Currency Devaluation in an Open-Shop Union, International Review of Economics and Finance 10, 61-74.

Lai, C., Yang, C. and J. Chang (2003), Environmental Regulations and Social Norms, International Tax and Public Finance 10, 63-75.

Lorenz, W. and J. Wagner (1991), Bestimmungsgründe von Gewerkschaftsmitgliedschaft und Organisationsgrad. Eine ökonometrische Analyse auf Mikrodatenbasis für die Bundesrepublik Deutschland, Zeitschrift für Wirtschafts- und Sozialwissenschaften 111, 65-82.

Manski, C.F. (1993), Identification of Endogenous Social Effects: The Reflection Problem, Review of Economic Studies 60, 531-542.

Manski, C.F. (2000), Economic Analysis of Social Interactions, Journal of Economic Perspectives 14, 115-136.

Moreton, D.R. (1998), An Open Trade Union Model of Wages, Effort and Membership, European Journal of Political Economy 14, 511-527.

Moreton, David (1999), A Model of Labour Productivity and Union Density in British Private Sector Unionised Establishments, Oxford Economic Papers 51, 322-344.

Myles, G.G. and R.A. Naylor (1996), A Model of Tax Evasion with Group Conformity and Social Customs, European Journal of Political Economy 12, 49-66.

Naylor, R.A. (1989), Strikes, Free Riders and Social Customs, Quarterly Journal of Economics 104, 771-785.

Naylor, R.A. (1990), A Social Custom Model of Collective Action, European Journal of Political Economy 6, 201-216.

Naylor, R.A. and M. Cripps (1993), An Economic Theory of the Open Trade Union, European Economic Review 37, 1599-1620.

Naylor, R.A. and O. Raaum (1993), The Open Shop Union, Wages and Management Opposition, Oxford Economic Papers 45, 589-604. 
Olson, M. Jr. (1965), The Logic of Collective Action, Harvard University Press.

Schnabel, C. and J. Wagner (2003a), Trade Union Membership in Eastern and Western Germany: Convergence or Divergence?, IZA Discussion Paper No. 707.

Schnabel, C. and J. Wagner (2003b), Determinants of Trade Union Membership in Western Germany: Evidence From Microdata, 1980-2000, IZA Discussion Paper No. 708.

SOEP Group (2001), The German Socio-Economic Panel after more than 15 years Overview, Vierteljahrshefte zur Wirtschaftsforschung 70, 7-14.

Visser, J. (2002), Why Fewer Workers Join Unions in Europe: a Social Custom Explanation of Membership Trends, British Journal of Industrial Relations 40, 403-430.

Wagner, J. (1990), Gewerkschaftsmitgliedschaft und Arbeitseinkommen in der Bundesrepublik Deutschland, Discussion Paper No. 155, University of Hannover.

Wagner, J. (1991), Gewerkschaftsmitgliedschaft und Arbeitseinkommen in der Bundesrepublik Deutschland, Ifo-Studien 37, 109-140.

Wagner, G., R. Burkhauser and F. Behringer (1993), The English Language Public Use File of the German Socio-Economic Panel, The Journal of Human Resources 28, 429-433.

Windolf, H. and J. Haas (1989), Who Joins the Union? Determinants of Trade Union Membership in West Germany 1974-1984, European Sociological Review 5, 147-165. 
Table 1

\begin{tabular}{|c|c|c|c|}
\hline \multicolumn{4}{|c|}{$\begin{array}{l}\text { Union Membership and Social Custom } \\
\text { - conditional fixed effects logit model (CFE) - }\end{array}$} \\
\hline & $C F E-I$ & $C F E-I I$ & $C F E-I I I$ \\
\hline \multirow[t]{2}{*}{ net union density $(u d)$} & $0.022 *$ & $0.013+$ & $0.019+$ \\
\hline & $(0.010)$ & $(0.008)$ & $(0.010)$ \\
\hline \multirow[t]{2}{*}{ father self-employed * ud } & $-0.09 *$ & $-0.09 *$ & -- \\
\hline & $(0.041)$ & $(0.041)$ & \\
\hline \multirow[t]{2}{*}{ "prefers SPD" * ud } & -0.029 & -- & -0.027 \\
\hline & $(0.020)$ & & $(0.019)$ \\
\hline \multirow[t]{2}{*}{ "prefers CDU/CSU" * ud } & -0.014 & -- & -0.018 \\
\hline & $(0.027)$ & & $(0.026)$ \\
\hline \multirow[t]{2}{*}{ Social Democrats (SPD) } & 0.749 & -- & 0.623 \\
\hline & $(0.619)$ & & $(0.612)$ \\
\hline \multirow{2}{*}{$\begin{array}{l}\text { Conservatives } \\
(C D U / C S U)\end{array}$} & 0.284 & -- & 0.394 \\
\hline & $(0.878)$ & & $(0.850)$ \\
\hline \multirow[t]{2}{*}{ qualified blue-collar worker } & 0.377 & 0.350 & 0.402 \\
\hline & $(0.314)$ & $(0.312)$ & $(0.310)$ \\
\hline \multirow{2}{*}{$\begin{array}{l}\text { unqualified white-collar } \\
\text { worker }\end{array}$} & -0.081 & -0.050 & -0.060 \\
\hline & $(0.407)$ & $(0.405)$ & $(0.401)$ \\
\hline \multirow[t]{2}{*}{ qualified white-collar worker } & -0.260 & -0.249 & -0.202 \\
\hline & $(0.423)$ & $(0.420)$ & $(0.414)$ \\
\hline \multirow{2}{*}{ firm size: $20 \leq X<200$} & $0.687^{*}$ & $0.700^{*}$ & $0.647^{*}$ \\
\hline & $(0.281)$ & $(0.280)$ & $(0.278)$ \\
\hline \multirow{2}{*}{ firm size: $200 \leq X<2000$} & $1.543 * *$ & $1.499 * *$ & $1.469 * *$ \\
\hline & $(0.317)$ & $(0.313)$ & $(0.313)$ \\
\hline \multirow{2}{*}{ firm size: $X \geq 2000$} & $1.883 * *$ & $1.895 * *$ & $1.805^{* *}$ \\
\hline & $(0.354)$ & $(0.354)$ & $(0.349)$ \\
\hline \multirow[t]{2}{*}{ tenure } & $0.136 * *$ & $0.136^{* *}$ & $0.147 * *$ \\
\hline & $(0.048)$ & $(0.047)$ & $(0.047)$ \\
\hline \multirow[t]{2}{*}{ tenure (squared) } & $-0.005^{*}$ & $-0.005^{*}$ & $-0.005 * *$ \\
\hline & $(0.002)$ & $(0.002)$ & $(0.002)$ \\
\hline \multirow[t]{2}{*}{ experience } & 0.025 & 0.027 & 0.025 \\
\hline & $(0.068)$ & $(0.067)$ & $(0.067)$ \\
\hline \multirow[t]{2}{*}{ experience (squared) } & $-0.003+$ & $-0.003+$ & $-0.002+$ \\
\hline & $(0.001)$ & $(0.001)$ & $(0.001)$ \\
\hline \multirow[t]{2}{*}{ log of monthly gross income } & 0.280 & 0.265 & 0.315 \\
\hline & $(0.311)$ & $(0.305)$ & $(0.307)$ \\
\hline Test_X $(d f)$ & $\chi^{2}(21)=100.5$ & $\chi^{2}(17)=98.4$ & $\chi^{2}(20)=96.3$ \\
\hline Test_ $\alpha_{i}(d f)$ & $\chi^{2}(21)=37.14$ & $\chi^{2}(17)=28.5$ & $\chi^{2}(20)=35.3$ \\
\hline Number of observations & 716 & 716 & 716 \\
\hline Number of individuals & 358 & 358 & 358 \\
\hline
\end{tabular}

Notes: Data source: German Socio Economic Panel (GSOEP). Dependent variable: union membership dummy.

Standard errors in parentheses, significance level: ${ }^{* *} \alpha<0.01 / * \alpha<0.05 /+\alpha<0.1$,

(df): degrees of freedom, set of regional dummies included.

Test_X: LR-Test with $\mathrm{H}_{0}$ : Set of estimated parameters are simultaneously equal to 0 .

Test_ $\alpha_{\mathrm{i}}$ : Hausman-test with $\mathrm{H}_{0}$ : Absence of individual fixed effects. 
Table 2

Union Membership and Social Custom

- linear probability model with fixed effects (LPM_FE)-

\begin{tabular}{|c|c|c|c|}
\hline & $L P M_{-} F E-I$ & $\overline{L P M} F E-\overline{I I}$ & LPM_FE-III \\
\hline \multirow[t]{2}{*}{ net union density $(u d)$} & $0.002 *$ & $0.002 *$ & $0.002 *$ \\
\hline & $(0.001)$ & $(0.001)$ & $(0.001)$ \\
\hline father self-employed $* u d$ & $\begin{array}{c}-0.004+ \\
(0.002)\end{array}$ & $\begin{array}{c}-0.004+ \\
(0.002)\end{array}$ & -- \\
\hline \multirow[t]{2}{*}{ "prefers $S P D " * u d$} & -0.002 & -- & -0.002 \\
\hline & $(0.002)$ & & $(0.002)$ \\
\hline \multirow[t]{2}{*}{ "prefers CDU/CSU" * ud } & -0.0004 & -- & -0.001 \\
\hline & $(0.002)$ & & $(0.002)$ \\
\hline \multirow[t]{2}{*}{ Social Democrats (SPD) } & 0.060 & -- & 0.055 \\
\hline & $(0.049)$ & & $(0.050)$ \\
\hline \multirow{2}{*}{$\begin{array}{l}\text { Conservatives } \\
(C D U / C S U)\end{array}$} & 0.006 & -- & 0.019 \\
\hline & $(0.062)$ & & $(0.062)$ \\
\hline \multirow[t]{2}{*}{ Qualified blue-collar worker } & 0.019 & 0.019 & 0.020 \\
\hline & $(0.026)$ & $(0.026)$ & $(0.026)$ \\
\hline \multirow{2}{*}{$\begin{array}{l}\text { unqualified white-collar } \\
\text { worker }\end{array}$} & -0.013 & -0.013 & -0.014 \\
\hline & $(0.032)$ & $(0.032)$ & $(0.032)$ \\
\hline \multirow{2}{*}{ qualified white-collar worker } & -0.031 & -0.031 & -0.030 \\
\hline & $(0.033)$ & $(0.033)$ & $(0.033)$ \\
\hline \multirow[t]{2}{*}{ firm size: $20 \leq X<200$} & $0.059 * *$ & $0.059 * *$ & $0.058 * *$ \\
\hline & $(0.022)$ & $(0.022)$ & $(0.022)$ \\
\hline \multirow[t]{2}{*}{ firm size: $200 \leq X<2000$} & $0.154 * *$ & $0.154 * *$ & $0.153 * *$ \\
\hline & $(0.026)$ & $(0.026)$ & $(0.026)$ \\
\hline \multirow{2}{*}{ Firm size: $X \geq 2000$} & $0.202 * *$ & $0.203^{* *}$ & $0.201 * *$ \\
\hline & $(0.028)$ & $(0.028)$ & $(0.028)$ \\
\hline \multirow[t]{2}{*}{ Tenure } & $0.012 * *$ & $0.012 * *$ & $0.012 * *$ \\
\hline & $(0.004)$ & $(0.004)$ & $(0.004)$ \\
\hline \multirow[t]{2}{*}{ tenure (squared) } & $-3 * 10-4 *$ & $-3 * 10-4 *$ & $-3 * 10-4 *$ \\
\hline & $(1 * 10-4)$ & $(1 * 10-4)$ & $(1 * 10-4)$ \\
\hline \multirow[t]{2}{*}{ Experience } & $4 * 10-5$ & $-2 * 10-4$ & $2 * 10-5$ \\
\hline & $(5 * 10-3)$ & $(5 * 10-3)$ & $(5 * 10-4)$ \\
\hline \multirow[t]{2}{*}{ experience (squared) } & $-2 * 10-4$ & $-1 * 10-4$ & $-1 * 10-4$ \\
\hline & $(1 * 10-4)$ & $(1 * 10-4)$ & $(1 * 10-4)$ \\
\hline \multirow[t]{2}{*}{ log of monthly gross income } & 0.026 & 0.028 & 0.030 \\
\hline & $(0.014)$ & $(0.022)$ & $(0.022)$ \\
\hline Test_X $(d f)$ & $\mathrm{F}(21,1861)=6.1$ & $F(17,1865)=7.4$ & $F(20,1862)=6.2$ \\
\hline Test_ $\alpha_{i}(d f)$ & $\mathrm{F}(1881,1861)=2.7$ & $\mathrm{~F}(1881,1865)=2.7$ & $\mathrm{~F}(1881,1862)=2.7$ \\
\hline Number of observations & 3764 & 3764 & 3764 \\
\hline Number of individuals & 1882 & 1882 & 1882 \\
\hline
\end{tabular}

Notes: Data source: German Socio Economic Panel (GSOEP). Dependent variable: union membership dummy.

Standard errors in parentheses, significance level: ** $\alpha<0.01 / * \alpha<0.05 /+\alpha<0.1$,

(df): degrees of freedom, set of regional dummies included.

Test_X: F-Test with $\mathrm{H}_{0}$ : Set of estimated parameters are simultaneously equal to 0 .

Test_ $\alpha_{i}$ : F-test with $\mathrm{H}_{0}$ : Absence of individual fixed effects. 
Reputation from membership is defined by equation (1) of the main text where density is measured as the ratio of union members to the fixed labour supply, normalised to unity. For convenience, we restrict the parameter $\beta$ to the interval $\beta \in[-1,1]$. Assuming the shift parameter $\mathrm{R}$ to exceed unity ensures that being a union member always yields a reputation gain in the absence of a membership fee $\left(\mathrm{r}^{\mathrm{i}}>0\right)$. Since employees who are characterised by high values of $\gamma$ join the union first, the marginal member $\mathrm{k}$ is defined by $\gamma^{\mathrm{k}}=1-\mathrm{m}$, for a uniform distribution of $\gamma$ on the interval $[0,1]$. Substituting in the reputation function (1) yields $r^{\mathrm{k}}=\mathrm{R}$ $-m^{\eta+1}+(1-\beta) m^{\eta}$. Given the assumptions of a wage-dependent membership fee, the possibility to remain a union member when unemployed, and an equal probability of employment for all workers, the expected utility of union membership $\mathrm{U}^{\mathrm{ui}}$ for an individual $\mathrm{i}$ is:

$$
U^{u i}=N(w)\left[u(w(1-g))+r^{i}\right]+(1-N(w))\left[u(B)+\alpha r^{i}\right]
$$

Since the wage is independent of union membership, the expected utility of non-membership $\mathrm{U}^{\mathrm{n}}$ is the same for all individuals and given by:

$$
U^{n}=N(w) u(w)+(1-N(w)) u(B)
$$

An employee will join the union if the expected gain $\mathrm{Z}^{\mathrm{i}} \equiv \mathrm{U}^{\mathrm{ui}}-\mathrm{U}^{\mathrm{n}}$ from doing so is positive.

$$
Z^{i}=N(w)[u(w(1-g))-u(w)]+\left[R+\gamma^{i} m^{\eta}-\beta m^{\eta}\right][N(w)(1-\alpha)+\alpha]
$$

The gain from joining or leaving the union for the marginal member $\mathrm{k}$ is $\tilde{Z} \equiv Z\left(\gamma^{\mathrm{k}}\right)=0$ :

$$
\tilde{Z}=N(w)\left\{u(w(1-g))-u(w)+(1-\alpha) r^{k}\right\}+\alpha r^{k}=0
$$

For $\tilde{Z}=0$, the term in curly brackets in (A.4) is non-positive. $\widetilde{Z}_{\mathrm{w}}>0$ holds for $\mathrm{u}^{\prime}(\mathrm{w}(1-\mathrm{g}))$ $\mathrm{u}^{\prime}(\mathrm{w}) /(1-\mathrm{g})>0$. Parametrically varying $\mathrm{m}$, a membership demand curve (MD) can be derived:

$$
\tilde{Z}_{m}=-(N(1-\alpha)+\alpha) m^{\eta-1}[(1+\eta) m-(1-\beta) \eta]
$$

For $\beta=1$ or $\eta=0, \tilde{Z}$ declines with membership. The membership demand curve of a union of elitists or sovereign employees has a positive slope. For conformists, $\beta \leq 0$ holds and the term in square brackets in (A.5) is positive for any $m>s \equiv \eta(1-\beta) /(1+\eta)$.

The wage bargaining curve (WB) results from the maximisation of the asymmetric Nashproduct, where $\rho(1-\rho)$ defines the union's (firm's) bargaining power. The firm's gain from bargaining is defined by its profits $\Pi$. The union maximises the (expected) utility of its 
median member $\mathrm{h}$, where $\gamma^{\mathrm{h}}=\left(1+\gamma^{\mathrm{k}}\right) / 2=1-\mathrm{m} / 2$. For $\mathrm{r}^{\mathrm{h}}=\mathrm{R}-0.5 \mathrm{~m}^{\eta+1}+(1-\beta) \mathrm{m}^{\eta}$, union utility is $\Omega=N\left[u(w(1-g))+r^{h}\right]+(1-N)\left[u(B)+\alpha r^{h}\right]$. In the case of no agreement, the median employee obtains unemployment benefits B and can retain the union status. Hence, the union's threat-point is $\mathrm{u}(\mathrm{B})+\alpha \mathrm{r}^{\mathrm{h}}$. This yields:

$$
V \equiv \frac{N u^{\prime}(w(1-g))(1-g)}{u(w(1-g))-u(B)+(1-\alpha)\left(R-\frac{m^{\eta+1}}{2}+(1-\beta) m^{\eta}\right)}-\frac{1-\rho}{\rho} \frac{N^{2}}{\Pi}+N_{w}=0
$$

Sufficient conditions for $\mathrm{V}_{\mathrm{w}}<0$ are: (1) the labour demand curve is weakly concave $\left(\mathrm{N}_{\mathrm{ww}} \leq\right.$ $0)$, (2) the sum of twice the labour demand elasticity and the ratio of labour cost to profits is positive (cf. Goerke and Pannenberg 1998). Moreover, for $\phi \equiv u(w(1-g))-u(B)+(1-\alpha) r^{h}$ :

$$
V_{m}=\frac{N u^{\prime}(w(1-g))(1-g)(1-\alpha)}{\phi^{2}} m^{\eta-1}\left[(1+\eta) \frac{m}{2}-(1-\beta) \eta\right]
$$

For a union of elitist or sovereign members $\mathrm{V}_{\mathrm{m}}>0$, such that the WB is upward sloping (see figure 2). For conformists, characterised by $\beta \leq 0$ and $\eta>0$, two cases can be distinguished. For $\mathrm{m}<2 \mathrm{~s}$, the WB is downward sloping, as $\mathrm{V}_{\mathrm{m}}<0$. For $\mathrm{m}>2 \mathrm{~s}, \mathrm{~V}_{\mathrm{m}}>0$ (see figure 3).

The specification in equations (2) and (A.3) implies that a worker decides about its membership prior to having knowledge about the employment status. Ex-post, i. e. after some workers have become unemployed, the incentives to be a member differ since the probabilities of obtaining a job play no role. This could give rise to adjustments in union membership. However, if jobs are allocated at random among the workforce, these membership dynamics would be of a short-run nature, not alter the long-run equilibrium union density and can, therefore, be ignored. The argument is the following: first, wages are determined on the basis of the membership level at the time of the bargain. If wages are then fixed, subsequent changes in union density will have no impact on wages and employment. Second, given the random determination of employment, all workers who might have found it favourable to reverse their decision subsequent to the last instance of wage determination, have an incentive to join the union again prior to the next bargain, which is not modelled here. Alternatively, it could be argued that workers are bound by their membership decision for the duration of a wage contract. 
Appendix II: Description and Means of Selected Variables

Table A1

\begin{tabular}{lcc}
\hline Variable & Mean & Mean \\
& LPM_FE & $C F E$ \\
\hline union member & 0.25 & 0.50 \\
net union density $(u d)$ & 27.42 & 28.39 \\
respondent prefers SPD *ud & 6.65 & 7.14 \\
respondent prefers CDU/CSU * ud & 3.56 & 2.31 \\
father self-employed & 0.09 & 0.04 \\
father self-employed $*$ ud & 2.345 & 1.23 \\
Social Democrats (SPD) & 0.24 & 0.24 \\
Conservatives (CDU/CSU) & 0.13 & 0.08 \\
qualified blue-collar worker & 0.23 & 0.27 \\
unqualified white-collar worker & 0.13 & 0.11 \\
Qualified white-collar worker & 0.32 & 0.22 \\
firm size:20 $\leq X<200$ & 0.34 & 0.34 \\
firm size: $200 \leq X<2000$ & 0.23 & 0.22 \\
firm size: $X \geq 2000$ & 0.19 & 0.25 \\
tenure (in years) & 7.70 & 6.65 \\
experience (in years) & 19.61 & 18.73 \\
log of monthly gross income & 7.96 & 7.95 \\
\hline Number of observations & 3764 & 716 \\
\hline
\end{tabular}

Note: Since only respondents who change union status contribute to the conditional likelihood function of the CFE-Model, the mean of the union member variable equals 0.5 by construction. 


\section{IZA Discussion Papers}

\begin{tabular}{|c|c|c|c|c|}
\hline No. & Author(s) & Title & Area & Date \\
\hline 947 & U. Sunde & $\begin{array}{l}\text { Potential, Prizes and Performance: Testing } \\
\text { Tournament Theory with Professional Tennis } \\
\text { Data }\end{array}$ & 7 & $12 / 03$ \\
\hline 948 & $\begin{array}{l}\text { A. Kugler } \\
\text { G. Pica }\end{array}$ & $\begin{array}{l}\text { Effects of Employment Protection and Product } \\
\text { Market Regulations on the Italian Labor Market }\end{array}$ & 6 & $12 / 03$ \\
\hline 949 & C. J. Flinn & $\begin{array}{l}\text { Minimum Wage Effects on Labor Market } \\
\text { Outcomes under Search with Bargaining }\end{array}$ & 6 & $12 / 03$ \\
\hline 950 & $\begin{array}{l}\text { P. Garibaldi } \\
\text { E. Wasmer }\end{array}$ & $\begin{array}{l}\text { Equilibrium Employment in a Model of Imperfect } \\
\text { Labor Markets }\end{array}$ & 1 & $12 / 03$ \\
\hline 951 & $\begin{array}{l}\text { P. Garibaldi } \\
\text { E. Wasmer }\end{array}$ & $\begin{array}{l}\text { Raising Female Employment: Reflexions and } \\
\text { Policy Tools }\end{array}$ & 5 & $12 / 03$ \\
\hline 952 & $\begin{array}{l}\text { O. Raaum } \\
\text { K. G. Salvanes } \\
\text { E. Ø. Sørensen }\end{array}$ & The Neighbourhood Is Not What It Used to Be & 3 & $12 / 03$ \\
\hline 953 & $\begin{array}{l}\text { O. Raaum } \\
\text { K. G. Salvanes } \\
\text { E. Ø. Sørensen }\end{array}$ & $\begin{array}{l}\text { The Impact of a Primary School Reform on } \\
\text { Educational Stratification: A Norwegian Study of } \\
\text { Neighbour and School Mate Correlations }\end{array}$ & 5 & $12 / 03$ \\
\hline 954 & $\begin{array}{l}\text { P. Portugal } \\
\text { J. T. Addison }\end{array}$ & Six Ways to Leave Unemployment & 6 & $12 / 03$ \\
\hline 955 & V. Grossmann & $\begin{array}{l}\text { Risky Human Capital Investment, Income } \\
\text { Distribution, and Macroeconomic Dynamics }\end{array}$ & 5 & $12 / 03$ \\
\hline 956 & $\begin{array}{l}\text { M. Fertig } \\
\text { C. M. Schmidt }\end{array}$ & $\begin{array}{l}\text { Gerontocracy in Motion? European Cross- } \\
\text { Country Evidence on the Labor Market } \\
\text { Consequences of Population Ageing }\end{array}$ & 5 & $12 / 03$ \\
\hline 957 & $\begin{array}{l}\text { M. Ebell } \\
\text { C. Haefke }\end{array}$ & $\begin{array}{l}\text { Product Market Deregulation and Labor Market } \\
\text { Outcomes }\end{array}$ & 6 & $12 / 03$ \\
\hline 958 & $\begin{array}{l}\text { T. Brück } \\
\text { J. P. Haisken-DeNew } \\
\text { K. F. Zimmermann }\end{array}$ & $\begin{array}{l}\text { Creating Low Skilled Jobs by Subsidizing } \\
\text { Market-Contracted Household Work }\end{array}$ & 5 & $12 / 03$ \\
\hline 959 & $\begin{array}{l}\text { T. Bauer } \\
\text { H. Bonin } \\
\text { U. Sunde }\end{array}$ & $\begin{array}{l}\text { Real and Nominal Wage Rigidities and the Rate } \\
\text { of Inflation: Evidence from West German Micro } \\
\text { Data }\end{array}$ & 1 & $12 / 03$ \\
\hline 960 & $\begin{array}{l}\text { A. Constant } \\
\text { K. F. Zimmermann }\end{array}$ & $\begin{array}{l}\text { Circular Movements and Time Away from the } \\
\text { Host Country }\end{array}$ & 1 & $12 / 03$ \\
\hline 961 & $\begin{array}{l}\text { C. N. Teulings } \\
\text { C. G. de Vries }\end{array}$ & $\begin{array}{l}\text { Generational Accounting, Solidarity and Pension } \\
\text { Losses }\end{array}$ & 3 & $12 / 03$ \\
\hline 962 & $\begin{array}{l}\text { L. Goerke } \\
\text { M. Pannenberg }\end{array}$ & $\begin{array}{l}\text { Norm-Based Trade Union Membership: } \\
\text { Evidence for Germany }\end{array}$ & 3 & $12 / 03$ \\
\hline
\end{tabular}

An updated list of IZA Discussion Papers is available on the center's homepage www.iza.org. 